\title{
ІрИНа СТЕПАНЕНКО
}

\section{ЛЮДИНОТВОРЧИЙ ПОТЕНЦІАЛ ФІЛОСОФІЇ: СТРАТЕГІЧНІ ПЕРСПЕКТИВИ ВИЩОЇ ОСВІТИ}

У статті розкрито людинотворчий потенціал філософії, який вбачається у тому, що філософія, як «мистецтво пізнання у свободі через творчість ідей», здатна допомогти особистості оволодіти мистецтвом мислення і мистецтвом жити, а також виводить ї̈ у широкий контекст сучас-

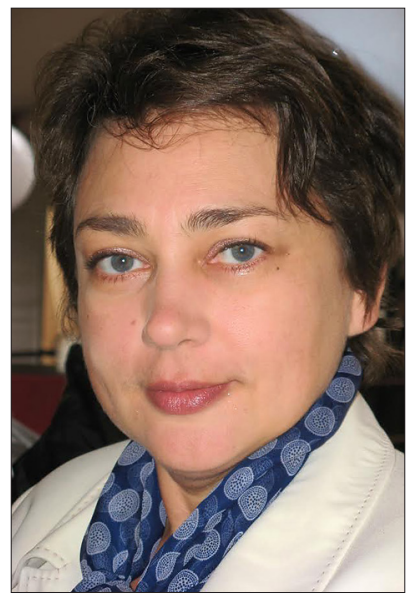
ності, утримуючи і відкриваючи у ньому універсальні цінності і смисли людяності, осягнені в їх минулих, сучасних і майбутніх формах, $i$, ти самим, виступає «захисницею» $i$ «терапевтом» людства. $У$ сучасних умовах, особливо у контексті Четвертої індустріальної революції, цей потенціал філософії є надзвичайно затребуваним і має бути максимально актуалізований у гуманістичних стратегіях вищої освіти. Але для иього філософії ( $і$ філософам) дуже важливо переконливо довести праксеологічну дієвість своїх основних функцій - гуманістичної, світоглядної, культуротворчої, терапевтичної і максимально розкрити свій людинотворчий потенціал і призначення у цілому. Що передбачає і відповідне оновлення самої філософської освіти.

Ключові слова: філософія, людинотворчий потенціал, універсальні смисли людяності, стратегічні перспективи вищої освіти, Четверта індустріальна революиія.

Питання, що пропонуються до розгляду, утворюють принаймні три взаємопов’язані і взаємообумовлені проблемні площини, кожна з яких відкриває простір для гострих теоретичних дискусій із найсерйознішими практичними наслідками. Це питання про долю людини, долю вищої, насамперед університетської освіти, і долю філософії. Увесь цей комплекс питань постав і надзвичайно загострився мірою універсалізації ринкових відносин у суспільному житті сучасної людини.

Закони ринку усе перетворюють на товар, який має приносити максимальний прибуток. Людина також перетворюється на товар, який користується попитом чи на ринку праці, чи на ярмарку марнославства i арені змагань за владу і панування. Для такої людини-товару із домінуючою ринковою орієнтацією головними стимулами і цілями є Гроші, Престиж і Влада. Але така людина, як про це писав ще Еріх Фромм, живе для чого завгодно, але лише не для себе і служить для задоволення чужих 
для себе інтересів (Фромм, 1993). Відтак вона втрачає відчуття осмисленості життя, здатність до продуктивного цілепокладання, смислотворення, самореалізації. Такий стан сучасної людини можна діагностувати як духовну хворобу, оскільки він заважає людині нормально жити і реалізовувати свій унікальний людський потенціал відповідно до свого покликання і призначення. Звідси випливають і такі хвороби сучасності, як ескалація жорстокості, агресивності, насильства, поширення асоціальної поведінки, саморуйнування через наркотики і алкоголь, ескапізм у суспільному і громадському житті, або надмірна самоексплуатація, яка призводить до самовигорання і саморуйнування, внутрішньої спустошеності, життєвого розчарування, суцільної самотності тощо.

Важлива роль у «лікуванні» цих духовних хвороб належить освіті, яка $з$ давніх часів розглядалася як друге, духовне народження людини. Але якщо сучасна середня освіта у розвинутих країнах Заходу стає все більш життєво орієнтованою і включає до своїх навчальних планів системну підготовку дитини до життя, то вища освіта ще суттєво відстає від переорієнтації на оволодіння мистецтвом жити як одну із своїх провідних стратегічних цілей. Тут склалася достатньо парадоксальна ситуація. Якщо на рівні декларацій і нормативних документів, що регулюють розвиток вищої освіти і в світі, і у нашій країні, проголошується орієнтація на гуманістичний розвиток людини, то на рівні менеджменту і фінансування панує логіка ринку і суто економічні міркування. Вища освіта перетворюється на комерціалізовану сферу надання освітніх послуг, де викладачі, як постачальники послуг, пропонують знання, навички і вміння у якості товарів для студентів як освітніх споживачів. Таким чином, комерціалізація освіти знаходить своє логічне завершення у їі комодифікації.

Небезпечність панування логіки ринку у царині вищої освіти визнається більшістю науковців і експертів. В усіх документах ЮНЕСКО, що визначають принципи розвитку вищої освіти для XXI століття, наголошується необхідність іiі радикального перетворення і переорієнтації на забезпечення культурного, соціально-економічного й екологічно стійкого розвитку людини, співтовариств і націй. У реалізації гуманістичного призначення вищої освіти вбачають необхідну передумову збереження за нею статусу суспільного блага і успішного виконання нею її соціальних функцій - формування у тих, хто навчається, соціальної відповідальності, громадянської і політичної позиції, почуття справедливості, міжнародного розуміння і розвитку, усього того, що є фундаментальними аспектами нашої спільної людяності. Показовим у цьому відношенні $є$ один із останніх документів ЮНЕСКО, присвячених вищій освіті, під назвою «Переосмислення освіти: у напрямку глобального загального 
блага?». Тут у підрозділі із відповідною назвою підтверджується гуманістичний підхід до освіти як центральне питання для сталого людського та соціального розвитку, в якому основна мета освіти має полягати в тому, щоб підтримати і зміцнити почуття власної гідності, здатності і благополуччя людини по відношенню до інших і до природи (ЮНЕСКО, 2015). Зрозуміло, що реалізація такого гуманістичного підходу неможлива при радикальному скороченні гуманітарних і філософських дисциплін в освітніх програмах університетів. Але саме таке скорочення відбувається у багатьох університетах світу, зокрема і в Україні, де ця тенденція набуває особливо загрозливого характеру у силу недостатньої продуманості і стратегічної визначеності освітніх реформ.

У реальних процесах інтеграції України до світового освітнього простору, зокрема євроінтеграційних (Болонський процес) переважає спрямованість на уніфікацію і стандартизацію у сфері вищої освіти, а за мету, передусім, ставиться підвищення іiі ринкової ефективності, що розуміється як пріоритетна орієнтованість на потреби ринку праці, оптимізація бюджетних видатків і підвищення конкурентоспроможності на світовому (європейському) ринку освітніх послуг. При цьому, розвиток людського потенціалу розглядається з точки зору його функціональної ефективності у межах логіки ринку праці. Про це свідчить уся ідеологія реформаційних заходів - реструктуризація системи держзамовлення у напряму радикального скорочення підтримки гуманітаріїв (і студентів, і науковців), критерії оцінювання ефективності вишів, викладачів і науковців, які не враховують специфіку гуманітарних і соціальних наук, прагнення перевести ці дисципліни у розряд дисциплін за вибором, що за умов недостатнього фінансування вишів призводить до радикального скорочення цих дисциплін в освітніх програмах тощо. Але така тенденція зневаги до фундаментальних засад вищої освіти - гуманістичних, культурних, аксіологічних суперечить не тільки покликанню і призначенню університету як території вільного розуму і вільного духу, що закріпилися за цим унікальним суспільним інститутом ще з часів В. фон Гумбольдта, але і потребам сучасного ринку праці, який стає все більш зацікавлений не стільки у функціонально спрямованих, вузько спеціалізованих фахівцях, скільки у фахівцях, що володіють здатністю складного і критичного мислення, які здатні осягнути і вирішувати проблеми високого, навіть глобального рівня відповідальності, здатні до творчості та інновацій, $є$ гнучкими та адаптивними до стрімких змін.

Питання про долю людини і призначення вищої освіти набувають ще одного смислу в умовах Четвертої індустріальної революції (4 IR), яку зараз переживає людська цивілізація. Для 4 IR характерне злиття технологій, які стирають межі між фізичною, цифровою і біологічною сфера- 
ми, що надає нові способи, в яких технологія буде вбудована в суспільство і навіть людське тіло. Складається нова антропологічна ситуація, i вища освіта має на неї адекватно відреагувати. Насамперед, йдеться про зайвість / не зайвість людини у світі (а у прикладному плані - на ринку праці) у зв'язку із глобальною роботизацією і створенням штучного інтелекту, що можуть відбутися у найближчі 10-20 років. Протягом усієї своєї попередньої історії людина підтверджувала свою буттєву затребуваність як істота, що здатна протистояти хаотичним силам світу, завдяки своїй спорідненості або із Космічним законом (Логосом, Дао тощо), або із Богом, Абсолютним Розумом, або завдяки силі свого розуму. Відповідно до цих уявлень вибудовувалися і релевантні освітні стратегії.

У перспективі появи робототехніки нового покоління і штучного інтелекту, які значно перевершують обчислювально-інструментальноопераційні можливості людського розуму, перед людиною постала потреба віднайти у собі те, що не зможуть замінити ані роботи, ані штучний інтелект. Або, як це висловив Клаус Шваб, засновник і виконавчий голова Всесвітнього економічного форуму, - «Зрештою, все зводиться до людей і цінностей. Ми повинні сформувати майбутнє, яке працює для всіх нас, ставлячи на перше місце людей і розширення їх прав та можливостей. У своїй найбільш песимістичній, дегуманізованій формі, 4 IR дійсно може призвести до “роботизації” людства i, таким чином, позбавити нас нашого серця і душі. Але як доповнення до кращої частини людської природи - креативність, емпатія, керівництво - це також може підняти людство на новий рівень колективної та моральної свідомості на основі загального здорового глузду. Ми зобов'язані зробити все, щоб переконатися, що останній переважає» (Schwab, 2016).

На думку експертів Всесвітнього економічного форуму, найбільш затребуваними у найближчому майбутньому у наслідок 4 IR будуть філософи і гуманітарії, оскільки саме для них найбільш притаманні такі soft skills як складне і критичне мислення, креативність - компетентності, що займають трійку лідерських позицій у топ-10 навичок, що будуть потрібні у 2020 році (Gray, 2016). Філософська освіта у цілому, навіть якщо вона не є фаховою, є головним інструментом формування мистецтва мислення, релевантного вимогам часу, потребам суспільства і особистості. Атрибутивні властивості філософського мислення, або мистецтва філософського мислення можна виразити за допомогою абревіатури «СКАЛА» - це мислення системне (складне), критичне, аналітичне, логічне, аргументоване. Але «вишколом розуму» (Я. Пелікан) гуманістична функція філософії у системі вищої освіти не вичерпується, як не вичерпується і гуманістична функція самої вищої освіти. 
Філософія, як теоретична форма світогляду, за своїм покликанням i призначенням завжди була пов'язана із проникненням у позамежну сутність світу, виявленням у ньому над утилітарних смислів і цінностей, усього того, що не локалізується у повсякденні і сьогоденні, не обмежується вузько прагматичними, одномоментними, егологічно-індивідуальними запитами, а утворює глибинні універсальні підвалини і наскрізну вертикаль людяності і людського світу. Більш розгорнуто цю думку висловив М. Бердяєв у своїй праці «Філософія свободи. Смисл творчості», наполягаючи, що за своєю сутністю і за своєю задачею філософія ніколи не була пристосуванням до необхідності і завжди прагнула бути звільненням людського духу від рабства у необхідності, здійснюючи пізнавальний опір світу наявному і необхідному, а не пристосовуючись до нього. У цьому філософія ближче до мистецтва, а не до науки і є мистецтвом пізнання у свободі через творчість ідей, які опираються світовій наявності і необхідності і проникають у позамежну сутність світу. Для підтримки життя у цьому світі філософія ніколи не була потрібна, так як наука, вона потрібна для виходу за межі наявного світу, саме такий вихід і робить їі життєздатною (Бердяєв, 1996: с. 262 -265).

Виходячи із такого розуміння філософії, використання у філософських дослідженнях посилання на «сьогодення» (яке часто трапляється у вітчизняних дисертаційних роботах) є, на нашу думку, не коректним. Філософія, як «духовна квінтесенція свого часу», як «епоха, схоплена у думці» (Г.В.Ф. Гегель), має справу не з сьогоденням - чимось безпосередньо даним, швидкоплинним і скороминучим, а із сучасністю, яка включає до себе, окрім сьогодення, ще і свої історичні передумови та майбутні перспективи, а також дійсне, можливе і потенційне (навіть неможливе), бажане і небажане тощо. У цьому розумінні саме сучасність задає визначальний контекст філософським дослідженням і міркуванням. Саме зв'язок із сучасністю, а не сьогоденням дозволяє філософії продуктивно відреагувати на нову антропологічну ситуацію, що склалася у наслідок 4 IR, і позиціонувати себе у вищій освіті «захисницею людства», як це виразив В. Гьофе, маючи на увазі насамперед людяність, а через неї і людський рід (Гьофе, 2002: с. 5).

В Україні потреба буттєвої і освітньої реабілітації філософії є особливо відчутною. Для цього є багато причин, які стосуються і недостатньо чіткого стратегічного розуміння ключових цілей і механізмів реформування вітчизняної системи вищої освіти (яке само потребує філософського обгрунтування), і ситуації у царині самої вітчизняної філософії, зокрема змісту і способу їі викладання. Вітчизняні «борці» із філософією в освітніх програмах розглядають їі як щось зайве, як пережиток минулого, коли вона була опорою радянської ідеології, вважають, що вона 
нічого позитивного не може дати сучасній вищій освіті, причому виходячи переважно із власного негативного досвіду вивчення філософії.

Таким чином, перед вітчизняною філософією стоїть завдання, навіть складніше, ніж перед філософією і філософами інших країн, пов'язане 3 необхідністю подолати свій залишковий пострадянський стан. Вона має здійснити свій системний «ребрендінг», пов'язаний із оновленням і власного наукового дискурсу, і його активного включення до світового філософського дискурсу, і оновленням свого суспільного іміджу і впливовості, і кардинального оновлення своїх освітніх програм і навчальних курсів, способів їх викладання у закладах вищої освіти, зокрема в університетах. Важливі кроки у цьому напрямі вже зроблені. Насамперед йдеться про розроблення стандартів філософської освіти (Пролеєв, 2016), але головний шлях ще попереду.

На цьому шляху філософії (і філософам) дуже важливо переконливо довести праксеологічну дієвість своїх основних функцій - гуманістичної, світоглядної, культуротворчої, максимально розкрити свій людинотворчий потенціал і призначення у цілому. Водночас, не менш важливо розуміти, що філософія не має безпосередньої утилітарної користі, і не очікувати цього від неї. Але це не означає, що вона взагалі не має ніякої користі. Вище ми вже розглядали такі складові людинотворчого потенціалу філософії, як «вишкіл розуму» (оволодіння мистецтвом мислити), продукування і відкриття над утилітарно значущих цінностей і смислів, «захист людяності». Але філософія має ще одну потенцію та інтенцію - оволодіння мистецтвом жити в античному сенсі «technique to be», де мистецтво постає, як майстерність, кваліфікація, вміння, вправність тощо, а буття у сенсі принципу буття Фромма, як продуктивно-творче розгортання і самоздійснення індивідуального життя. У такому сенсі оволодіння мистецтвом жити постає не просто як підготовка до життя у його повсякденному перебігу, а як формування компетентності щодо саморозвитку (self-development) - самовизначення і самоздійснення у «неминучих горизонтах загальних значень» (Ч. Тейлор). Прикметно, що ЮНЕСКО четверту ціль освіти для ХХІ століття позначила саме «вчитися, щоб бути» (learning to be), а не вчитися, щоб жити. Остання настанова орієнтує швидше на розвиток у особистості адаптивних здібностей і вміння вирішувати поточні проблеми повсякденного життя і мало пов'язана із філософією. Але саме така настанова переважно і впроваджується у систему середньої освіти в Україні, що знаходить вираження у відповідних навчальних предметах. Сучасна ж людина має бути не тільки і не стільки адаптивною, скільки інноваційною і креативною, постійно виходити за межі свого досвіду, розширювати свої можливості, долати наявні границі, але водночас, усвідомлювати 
границі людяності і людського співбуття, керуватися принципом відповідальності за можливість продовження прийдешніх поколінь людей (Г. Йонас). І тут вже без філософії мистецтва жити не обійтися.

Здавалось би загальновизнано, що філософія із самого початку свого виникнення постає як необхідна передумова духовного життя і саморозвитку людини, як засіб іiї свідомої орієнтації у світі та у власному житті. Вже Цицерон визначав філософію як засіб культивування душі. Покликання і призначення філософії визнається ії здатністю задовольняти фундаментальні духовні потреби людини, такі, як потреба в осмисленні світу, у внесенні у життя смислу, потреба у життєвій орієнтації, потреба осмислити світ як єдиний і цілісний у своїй основі. Але саме цей потенціал філософії розкривається у вітчизняних навчальних курсах і підручниках найменше. Вони значною мірою відтворюють структуру і підходи до викладання, що склалися за радянських часів. У кращому разі відбувається заміна (часто формальна) гносеології на епістемологію, філософії свідомості на феноменологію, до класичної онтології чи соціальної філософії радянського зразка додаються окремі сучасні підходи, а в історії філософії прибираються пасажі щодо боротьби матеріалізму та ідеалізму. Найбільш радикальна зміна зводиться до максимального усунення посилання на марксистську традицію, але при суттєвому збережені духу марксистсько-ленінської філософії. Показовим у цьому відношенні є достатньо поширене у навчальній літературі і на українських просторах Інтернету визначення філософії як «науки про найбільш загальні закони розвитку природи, суспільства, людини», при тому, що за радянських часів так визначалася не уся філософія, а марксистська діалектика. Філософія ж мистецтва жити із притаманною їй терапевтичною функцією у навчальних курсах практично не представлена. Між тим, терапевтична функція філософії займає не останнє місце у їі людинотворчому потенціалі. Не останнє як з точки зору історичної генези філософії, так і з точки зору іiі затребуваності з боку сучасної людини, яка все більш напружено шукає шлях до себе і намагається осягнути параметри доброго життя - життя яке гідне утвердження.

Філософія з моменту свого зародження у стародавньому світі складалася не тільки як теоретична форма духовного освоєння світу, спрямована на визначення і обгрунтування першооснов і першопринципів буття, а і як особлива форма опанування культурою себе - турботи про себе шляхом удосконалення своєї душі за допомогою розуму, як мистецтво жити. Філософія як мистецтво жити заявила про себе і у Давньому Китаї, Давній Індії, Давній Греції. Але свій розквіт і своє справжнє «золоте сторіччя» вона пережила в елліністичний період античної філософiї, де постала і як розвинута теорія, і як життєва практика. Причому фі- 
лософія мистецтва жити як практика себе з самого початку і, особливо у після платонівській традиції, зближувалася із лікувальною діяльністю. Про таке зближення свідчить насамперед, як це показує М. Фуко, спільність концептуального поля і понятійного каркасу медицини і філософіï: «Центральним для нього є поняття pathos, яке і епікурейці, і стоїки тлумачать як пристрасть і хворобу..» (Фуко, 2007: с. 114). Але ще більший простір для роздумів дає та обставина, що «практика себе, як вона визначається, позначається і приписується філософією, розуміється як лікувальна діяльність. Центральним при цьому, зрозуміло, є поняття therapeuein. Therapeuein грецькою, як ви знаєте, позначає три речі. Перше - це те, що робить лікар для зцілення хворого, але therapeuein - це ще і дії слуги, який служить своєму пану і виконує його накази; нарешті therapeuein означає почитати, відправляти культ». Так ось, therapeuein heauton означає одночасно лікуватися, служити самому собі і почитати самого себе» (Фуко, 2007: с. 115). Крім того, на думку Філона Олександрійського, філософи можуть називати себе терапевтами, тому що вони лікують душу і лікують буття (Фуко, 2007: с. 116).

Сучасна людина безумовно потребує такої філософської терапії. Нерозумні рухи душі сучасної людини набули таких форм і досягли таких масштабів, що загрожують самому існуванню людського роду і життя на планеті Земля. Таким чином, лікування душі $є$ і необхідною передумовою для лікування буття. Визнання за філософією такої терапевтичної функції зовсім не означає спростування чи заміну усіх її інших функцій і предметів осмислення. Але за ними можна побачити іiі терапевтичну місію, коли філософія здійснює діагностику сучасного стану суспільства і стану сучасної людини, коли вона намагається знайти і обгрунтувати критерії «доброго життя» і гідного образу людини як важливі «ліки» від хвороб сучасності, коли вона формує і розвиває культуру мислення, коли вона звільняє людський дух від «рабства у необхідності», здійснюючи терапію духу і уможливлюючи само його існування. У своїх попередніх публікаціях ми вже неодноразово зверталися до обгрунтування мистецтва життєтворчості як стратегічного орієнтиру сучасної вищої освіти (див., наприклад, Степаненко, 2013), тому зараз лише стисло окреслимо отримані раніше висновки, які можуть слугувати і висновками для цієї розвідки.

Наскрізною для філософії мистецтва жити є ідея турботи про себе і культури себе, оскільки предметом філософії мистецтва жити вважається не життя само по собі, а людина як головний творець цього життя. Відповідно стратегія гуманізації вищої освіти має бути спрямована на формування особистості як відповідального, активного і творчого 
суб’єкта власного життя із використанням усього людинотворчого потенціалу філософії.

Ще одна наскрізна ідея - у справі життєтворчості важливо як можна раніше почати і ніколи не зупинятися. Ця ідея корелює із вимогами концепції навчання впродовж усього життя і орієнтує на формування життєтворчих спрямувань особистості, її здатності вчитися і перенавчатися, самовизначатися і саморозвиватися вже із раннього віку і на всіх подальших етапах освіти, що суттєво підносить роль педагога і необхідність організовувати освіту, насамперед педагогічну, на життєтворчих засадах. Причому викладач має відмовитись від ролі «транслятора знань» на користь ролі наставника, що знаходить підтвердження у таких сучасних формах, як тьютер, коучер, фасилітатор тощо.

У сучасних умовах проблема оволодіння мистецтвом жити міститься не тільки в площині вимоги «почати жити для себе», а й в площині вимоги будувати своє життя і здійснювати свою життєдіяльність і професійну діяльність на засадах етики відповідальності (Г. Йонас), бути відповідальним суб‘єктом суспільного розвитку в умовах глобалізації ризиків і невизначеності образу майбутнього, що суттєво підсилює ризикогенність індивідуального життя і усіх процесів життєздійснення (Степаненко, 2013: с. 158).

Мистецтво жити як культурне явище має гуманістичне, духовно-моральне наповнення. «Воно пов’язане з удосконаленням особистості, піднесенням іiі життєвих спрямувань, оволодінням моральними чеснотами, розвитком здатності володарювати над своїми примхами і лікувати свої вади» (Сохань, 1996: с. 159). Таким чином, актуалізація філософії мистецтва жити у навчальних курсах філософії може не тільки надати більшої життєздатності філософії і зробити іiі більш затребуваною для студентства, але може сприяти і більш активному залученню гуманістичних засад у розвиток університетської освіти.

\section{Література:}

1. Бердяев Н. (1989) Философия свободы. Смысл творчества. М.: Правда, 1989. $608 \mathrm{c}$.

2. Гьофе В. (2002) Демократія в епоху глобалізації. - Київ: ППС. - 2002. - 436 с.

3. Пролеєв С. (2016) Філософські компетентності: якими їм бути? / Сергій Пролеєв // Філософія освіти. Philosophy of Education: науковий журнал. - 2016. № 2 (19) // Інститут вищої освіти НАПН України. Нац. Пед. Ун-т імені М.П. Драгоманова. - С. 88-96.

4. Сохань Л. (1996) Психологія і педагогіка життєтворчості: Навч.-метод. посібник / Ред. рада: В.М. Доній (голова), Г.М. Несен (заст. голови), Л.В. Сохань, І.Г. Єрмаков (наук. ред.) та ін. - К., 1996.- 791 с.

5. Степаненко I. (2013) Філософія мистецтва жити: концептуальні контури і освітні імплікації у суспільстві ризику / Ірина Степаненко, Наталія Степаненко // Фі- 
лософія освіти. Philosophy of Education: науковий журнал. - 2013. № 1 (12) // Інститут вищої освіти НАПН України. Нац. Пед. УН-т імені М.П. Драгоманова. - С. $140-161$.

6. Фромм Э. (1993) Человек для самого себя // Фромм Э. Психоанализ и этика. М.: Республика, 1993. - С. 19-191.

7. Фуко М. (2007) Герменевтика субъекта: Курс лекцій, прочитанных в Коллеж де Франс в 1981-1982 учебном году / М. Фуко; Пер. с фр. А.Г. Погоняйло. - СПб: Наука, 2007. - 677 с.

8. Gray Alex (2016) The 10 skills you need to thrive in the Fourth Industrial Revolution. Posted on 19 Jan 2016. URL: https://www.weforum.org/agenda/2016/01/the-10-skillsyou-need-to-thrive-in-the-fourth-industrial-revolution/.

9. Schwab Klaus (2016) The Fourth Industrial Revolution: what it means, how to respond. Posted on 14 Jan 2016. URL: https://www.weforum.org/agenda/2016/01/the-fourthindustrial-revolution-what-it-means-and-how-to-respond/

10. UNESCO (2015) Rethinking Education: Towards a Global Common Good? (2015) By Sobhi Tawil and Rita Locatelli, UNESCO Education Research and Foresight. Posted on May 15, 2015 by norrag. URL: https://norrag.wordpress.com/2015/05/15/ rethinking-education-towards-a-global-common-good/.

\section{Ирина Степаненко. Человекотворческий потенциал философии: стратеги- ческие перспективы высшего образования}

В статье раскрыт человекотворческий потенциал философии, который усматривается в том, что философия, как «искусство познания в свободе через творчество идей», способна помочь личности овладеть искусством мышления и искусством жить, а также выводит ее в широкий контекст современности, удерживая и открывая в нем универсальные ценности и смыслы человечности, постигнутые в их прошлых, современных и будущих формах, и, тем самым, выступает «защитницей» и «терапевтом» человечества. В современных условиях, особенно в контексте Четвертой индустриальной революции, этот потенциал философии является чрезвычайно востребованным и должен быть максимально актуализирован в гуманистических стратегиях высшего образования. Но для этого философии и философам весьма важно убедительно доказать праксеологическую действенность своих основных функций - гуманистической, мировоззренческой, культуротворческой, терапевтической и максимально раскрыть свой человекотворческий потенциал и предназначение в целом. Что предполагает и соответствующее обновление самого философского образования.

Ключевые слова: философия, человекотворческий потенциал, универсальные смыслы человечности, стратегические перспективы высшего образования, Четвертая индустриальная революция.

Irina Stepanenko. Human creative potential of philosophy: a strategic perspective of higher education

The paper reveals the human creative potential of philosophy, which is seen in the fact that philosophy, as "the technique of knowledge in freedom through 
creation of ideas", can help the personality to master the technique of thinking and technique to be, and brings him/her into the broad contemporary context, which holds and opens the universal values and sense of humanity, comprehented in their past, present and future forms, and thus acts as a "advocate" and "therapist" of humanity. This potential of philosophy is extremely pertinent and should be actualized in the humanistic strategies of higher education in modern conditions, especially in the context of the Fourth Industrial Revolution. But for that philosophy (and philosophers) has to prove the praxeology effectiveness of its core functions - humanistic, worldview, cultural, therapeutic and maximize its human creative potential and mission in general. That implies an update of the philosophical education.

Key words: philosophy, human creative potential, universal sense of humanity, a strategic perspective of higher education, the Fourth Industrial Revolution.

Степаненко Ірина Володимирівна - доктор філософських наук, професор, завідувач відділу інтернаціоналізації вищої освіти Інституту вищої освіти НАПН України, професор кафедри соціальної філософії, філософії освіти та освітньої політики Національного педагогічного університету імені М. П. Драгоманова, голова спеціалізованої вченої ради Д 26.456.01 Інституту вищої освіти НАПН України, член редакційної ради наукового журналу Філософія освіти. Philosophy of Education.

Stepanenko Iryna Vladimirovna - Doctor of philosophical Sciences, Professor, Head of the Department of Internationalization of Higher Education, Institute of Higher Education NAES of Ukraine; Professor of Department of Social Philosophy, Philosophy of Education and Educational Policy, N. Drahomanov National Pedagogical University; Chairman of the Specialized Scientific Council D 26.456.01, Institute of Higher Education of NAPS of Ukraine; Member of the Editorial Board of the Scientific Journal Філософія освіти. Philosophy of education. 